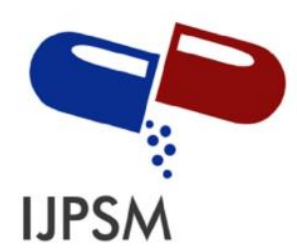

Rahma Yuni Safitri et al, Int. Journal of Pharmaceutical Sciences and Medicine (IJPSM),

Vol.6 Issue. 4, April- 2021, pg. 12-24

ISSN: 2519-9889

Impact Factor: 3.426

\title{
Overview of the Determination of Clonidine Levels in Pharmaceutical Preparations
}

\author{
Rahma Yuni Safitri; Roslinda Rasyid; Regina Andayani; Harrizul Rivai* \\ Faculty of Pharmacy, Andalas University, Limau Manih Campus, Padang 25163, Indonesia \\ "Email: harrizul@yahoo.co.id and harrizul@ phar.unand.ac.id \\ DOI: 10.47760/ijpsm.2021.v06i04.002
}

\begin{abstract}
Clonidine is an $\alpha 2$ - central agonist class of drugs widely used to treat cardiovascular diseases such as hypertension, heart attacks and help prevent strokes. The quality and safety of a drug preparation can be proven by testing the drug's quality assurance. In drug quality assurance, it is necessary to determine drug levels. Therefore, it is essential to look at the determination of clonidine levels in raw materials, mixtures, and pharmaceutical preparations. It is collecting data in this review article through trusted sites such as Google Scholar with the search keywords "clonidine hydrochloride," "clonidine analysis in pharmaceutical preparations" with a span of the last ten years (2010-2020). This review article aims to provide an overview of the various analytical techniques used to determine clonidine both in single substance form and in the pharmaceutical dosage form. Several analytical methods, such as UV-Visible spectrophotometry, potentiometry, highperformance liquid chromatography (HPLC), and high-performance thin-layer chromatography (HPTLC), have been reported to determine clonidine in the form of raw materials, mixtures, and pharmaceutical preparations. Overall, the determination of clonidine levels has been carried out by various analytical methods, including spectrophotometry, potentiometry, highperformance liquid chromatography (HPLC), and high-performance thin-layer chromatography (HPTLC). Analysis with the HPLC technique is widely used in research because it can detect samples with the lowest concentration. The HPLC-MS method has unique advantages and sensitivity in the analysis of clonidine in pharmaceutical preparations.
\end{abstract}

Keywords: Clonidine, spectrophotometry, potentiometry, HPLC, MS, HPTLC, pharmaceutical preparations.

\section{Introduction}

Clonidine is classified as $\alpha 2$-central agonists, widely used to manage cardiovascular diseases such as hypertension, heart attacks and help prevent stroke. Clonidine is also used for the prevention of headaches and can treat mental disorders/hyperactivity in children. $\alpha 2$-central agonists act by stimulating $\alpha 2$ adrenergic receptors in the brain, which reduce sympathetic flow from the vasomotor center and increase vagal tone. Peripheral stimulation of presynaptic $\alpha 2$ receptors led to decreased sympathetic tone. The result showed reduced heart rate, total peripheral resistance, plasma renin activity, and baroreceptor reflex [1].

The quality and safety of a drug preparation can be proven by testing the drug's quality assurance. In drug quality assurance, it is necessary to determine drug levels. Therefore, it is essential to look at the determination of clonidine levels in raw materials and pharmaceutical preparations. Medicines that have good quality will support the achievement of the expected therapeutic effect. One of the requirements for drug quality is that the drug content refers to the Indonesian Pharmacopeia requirements. The clonidine content stated in the Indonesian Pharmacopoeia is not less than $98.5 \%$ and not more than $101.0 \% \mathrm{C}_{9} \mathrm{H}_{9} \mathrm{Cl}_{2} \mathrm{~N}_{3} \cdot \mathrm{HCl}$, calculated for dry matter [2]. 


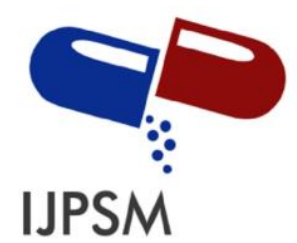

\section{Rahma Yuni Safitri et al, Int. Journal of Pharmaceutical Sciences and Medicine (IJPSM), Vol.6 Issue. 4, April- 2021, pg. 12-24}

ISSN: 2519-9889

Impact Factor: 3.426

Clonidine hydrochloride has the chemical name 2-[(2,6-Dichlorophenyl)imino] imidazolidine monohydrochloride [42095-91-8]. The chemical formula is $\mathrm{C}_{9} \mathrm{H}_{9} \mathrm{Cl}_{2} \mathrm{~N}_{3} \cdot \mathrm{HCl}$, and the molecular weight is 266.55. The structural formula for clonidine hydrochloride can be seen in Figure 1 [2].

Clonidine is a white crystalline powder. It has a boiling point of $305{ }^{\circ} \mathrm{C}$. It soluble in water and ethanol, rather difficult to dissolve in dehydrated alcohol, very difficult to dissolve in chloroform, and practically insoluble in ether. The partition coefficient value in octanol/water is 1.59 , and the clonidine $\mathrm{pKa}$ value at room temperature is 8.3 [3].

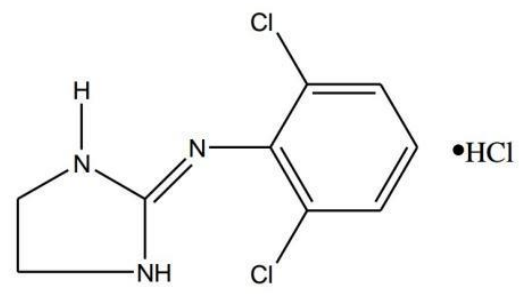

Figure 1: Structure of the clonidine [2].

Based on the obtained pharmacokinetic data, the absorption of clonidine is well absorbed after oral administration. Peak plasma concentrations are reached after 3 - 5 hours of oral administration. This drug is distributed into breast milk. It is across the placenta, about $40-60 \%$ of a single dose is excreted in the urine unchanged within 24 hours, and $20 \%$ of the dose is eliminated within four days via enterohepatic circulation. Some inactive metabolites have been detected in the urine in small amounts. Clonidine is absorbed through the skin, the therapeutic concentration is reached after 2 or 3 days after applying the transdermal delivery system, and maintained for 8 hours after transfer. The drug is metabolized primarily in the liver into several inactive metabolites and is excreted in the urine in an unchanged form [3,4].

Several methods have been reported related to clonidine analysis in either pure compounds, single substances, or formulations. Many analytical methods have been developed for the quantitative determination of clonidine levels, summarized from the last ten years' data (2010 - 2020).

\section{Method of collecting data}

Search data in this review article by collecting data from sources and literature in the form of pharmaceutical books and online research journals on the internet through trusted sites such as Google Scholar, NCBI, ResearchGate, and ScienceDirect with the search keywords "Clonidine Determination," "Clonidine Hydrochloride," "Analysis of Clonidine in Pharmaceutical Preparations." Data obtained from journals with inclusion criteria, namely journals published from 2010 to 2020, are discussed about the analytical methods used to determine the levels of clonidine drugs used during the last ten years.

\section{Clonidine analysis method}

\subsection{Ultraviolet spectrophotometric analysis}

Several ultraviolet spectrophotometric analysis methods have been used to determine clonidine levels in raw materials, mixtures, and pharmaceutical preparations (Table 1). 


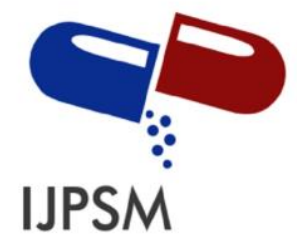

Rahma Yuni Safitri et al, Int. Journal of Pharmaceutical Sciences and Medicine (IJPSM), Vol.6 Issue. 4, April- 2021, pg. 12-24

ISSN: 2519-9889

Impact Factor: 3.426

Table 1: Clonidine analysis using ultraviolet spectrophotometry

\begin{tabular}{|l|l|l|c|c|c|}
\hline No. & Sample & Reagent & $\begin{array}{c}\text { Wavelength } \\
(\mathbf{n m})\end{array}$ & $\begin{array}{c}\text { Range of } \\
\text { Concentration }\end{array}$ & Ref. \\
\hline 1. & $\begin{array}{l}\text { Clonidine } \mathrm{HCl} \text { tablets, } \\
\text { and 2,6 } \\
\text { dichloroaniline } \\
\text { formulations and raw } \\
\text { materials }\end{array}$ & $\begin{array}{l}\text { Methanol, } \mathrm{HCl} \\
0,1 \mathrm{~N}\end{array}$ & $228,4 \mathrm{~nm}$ & $7,2 \mu \mathrm{g} / \mathrm{mL}$ & {$[5]$} \\
\hline 2. & $\begin{array}{l}\text { Clonidine } \mathrm{HCl} \text { and } \\
\text { hydrochlorothiazide } \\
\text { tablets in } \\
\text { pharmaceutical } \\
\text { formulations }\end{array}$ & Methanol & $315 \mathrm{~nm}$ & $2-10 \mu \mathrm{g} / \mathrm{mL}$ & {$[6]$} \\
\hline 3. & $\begin{array}{l}\text { Clonidine } \mathrm{HCl} \text { tablets } \\
\text { in pharmaceutical raw } \\
\text { materials and } \\
\text { preparations }\end{array}$ & Ethanol & $280 \mathrm{~nm}$ & $6-14 \mu \mathrm{g} / \mathrm{mL}$ & \\
\hline
\end{tabular}

Reliable and straightforward spectrophotometric methods have been developed for the determination of clonidine in formulations and raw materials. Clonidine $\mathrm{HCl}$ tablets were analyzed by three rapid, sensitive and selective analytical techniques designed to determine clonidine hydrochloride and its related substance: 2,6dichloroaniline in a mixture of the two. The first method relies on ratio-derivative spectrophotometry in which the first-derivative signal of the radio spectrum at $228.4 \mathrm{~nm}(\Delta \lambda=2 \mathrm{~nm})$ is selected for the determination of clonidine hydrochloride. The second method is based on measuring the response of the first-derivative 2,6dichloroaniline at $300.8 \mathrm{~nm}$ without interference from intact clonidine hydrochloride. In a third method, 2,6dichloroaniline was determined by diazotization and combination with $\mathrm{N}$-(1-naphthyl) ethylenediamine to give a colored azodye measured at $498 \mathrm{~nm}$. Different parameters affecting each method are studied and optimized. The proposed method was validated following USP guidelines regarding linearity, range, accuracy, precision, detection, and quantification limits. The derivative ratio spectrophotometric method was applied to analyze clonidine hydrochloride in tablets, and the results were found according to the USP XXX HPLC procedure. In contrast, the second and third methods allowed the selective analysis of 2,6-dichloroaniline in clonidine hydrochloride feedstock [5].

Development and validation of a UV spectrophotometric method simultaneously determine clonidine hydrochloride and hydrochlorothiazide in tablet formulations measured at three wavelengths. The standard compounds and samples of clonidine hydrochloride and hydrochlorothiazide were dissolved in methanol. This method fulfills the linearity test in the range $6-14 \mu \mathrm{g} / \mathrm{mL}$ and $2-10 \mu \mathrm{g} / \mathrm{mL}$ with correlation coefficient values of 0.992, 0.993, and 0.986 for clonidine $\mathrm{HCl}$, and 0.993, 0.999, 0.995 for hydrochlorothiazide. Samples were measured at $315 \mathrm{~nm}, 280 \mathrm{~nm}, 296 \mathrm{~nm}$ for clonidine $\mathrm{HCl}$, and $317 \mathrm{~nm}, 269 \mathrm{~nm}, 226 \mathrm{~nm}$ for hydrochlorothiazide. This method is fast, simple, and efficient for concurrent analysis of clonidine $\mathrm{HCl}$ and hydrochlorothiazide [6].

A simple, fast, economical, precise, and accurate area under curve method has been developed to determine clonidine $\mathrm{HCl}$ in raw materials and pharmaceutical preparations. The standard compound and clonidine hydrochloride samples were dissolved in ethanol. The wavelength range selected for analysis was 201-211 nm. Linearity was found to be between $1-5 \mu \mathrm{g} / \mathrm{mL}$. The percentages for commercial formulations are located in the range $99.93-100.03 \%$. Recovery was found in the field $99.94-99.97 \%$. The analysis results were statistically validated, and retrieval studies confirmed the proposed method's accuracy and reproducibility following the ICH guidelines [7]. 


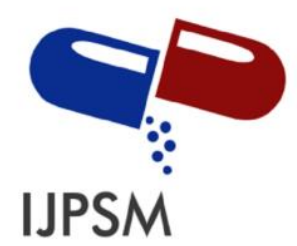

Rahma Yuni Safitri et al, Int. Journal of Pharmaceutical Sciences and Medicine (IJPSM), Vol.6 Issue. 4, April- 2021, pg. 12-24

ISSN: 2519-9889

Impact Factor: 3.426

\subsection{Visible spectrophotometric analysis}

Several visible spectrophotometric analysis methods have been used to quantitatively analyze clonidine levels in the form of mixtures and pharmaceutical preparations (Table 2).

Table 2: Clonidine analysis using visible spectrophotometry

\begin{tabular}{|l|l|l|c|c|c|}
\hline No. & Sample & Reagent & $\begin{array}{c}\text { Wavelength } \\
(\mathbf{n m})\end{array}$ & $\begin{array}{c}\text { Range of } \\
\text { Concentration }\end{array}$ & Ref. \\
\hline 1. & $\begin{array}{l}\text { Clonidine HCl tablets } \\
\text { in pharmaceutical } \\
\text { dosage forms }\end{array}$ & $\begin{array}{l}\text { Methanol, } \\
\text { distilled water }\end{array}$ & $\begin{array}{c}418 \mathrm{~nm} / 448 \\
\mathrm{~nm}\end{array}$ & $0,5-7,5 \mu \mathrm{g} / \mathrm{mL}$ & {$[8]$} \\
\hline 2. & Simultaneous tablets & Distilled water & $765 \mathrm{~nm}$ & $4-28 \mu \mathrm{g} / \mathrm{mL}$ & {$[9]$} \\
& of clonidine HCl, & & $740 \mathrm{~nm}$ & $6-42 \mu \mathrm{g} / \mathrm{mL}$ & \\
& nevirapine, stavudine & & $755 \mathrm{~nm}$ & $2-14 \mu \mathrm{g} / \mathrm{mL}$ & \\
& in the form of & & & & \\
& pharmaceutical raw & & & & \\
& materials and & & & & \\
& pharmaceutical & & & & \\
preparations & & & & \\
\hline
\end{tabular}

A study describes the development of a spectrophotometric method and the validation of clonidine hydrochloride in pharmaceutical preparations with higher precision and accuracy. The purpose of this study was to determine the conditions of two spectrophotometric methods for the determination of clonidine in two tablet samples based on the formation of an ion-pair complex between clonidine hydrochloride and thymol blue or bromophenol blue. Spectrophotometric measurements were carried out using Jasco's double beam (model V-530). A UV-visible spectrophotometer with a pair of quartz cells measuring $1 \mathrm{~cm}$ with a scan speed of $1000 \mathrm{~mm}$ min-1 has been developed in the determination of clonidine, and the maximum absorbance was measured at $418 \mathrm{~nm} / 448 \mathrm{~nm}$ against blank solutions. After validation, the method was used to determine the levels of clonidine hydrochloride in two tablet samples. Active substance recovery varied between 98.06 and $100.13 \%$ without interference from excipients [8].

UV Vis spectrophotometric methods that do not require extraction to determine clonidine in pharmaceutical raw materials and tablet dosage forms have been developed. There are three drug samples, namely clonidine hydrochloride, nevirapine, stavudine. In this procedure, the drug compound is reacted with the Folin-Ciocalteu reagent in an alkaline medium. It produces blue chromogen, which shows $\lambda_{\max }$ at $765 \mathrm{~nm}, 740 \mathrm{~nm}, 755 \mathrm{~nm}$ with a concentration range of $4-28 \mu \mathrm{g} / \mathrm{mL}, 6-42 \mu \mathrm{g} / \mathrm{mL}, 2-14 \mu \mathrm{g} / \mathrm{mL}$ each for the drug clonidine, nevirapine, stavudine. This spectrophotometric method is simple, fast, and extraction-free and can be used for quality control and drug stability [9].

\subsection{Potentiometric analysis}

Several potentiometric methods using membranes have been used quantitatively to analyze clonidine levels in pharmaceutical preparations (Table 3). 


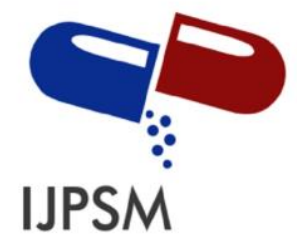

Rahma Yuni Safitri et al, Int. Journal of Pharmaceutical Sciences and Medicine (IJPSM), Vol.6 Issue. 4, April- 2021, pg. 12-24

ISSN: 2519-9889

Impact Factor: 3.426

Table 3: Clonidine analysis using a potentiometric sensor

\begin{tabular}{|c|c|c|c|c|c|}
\hline No. & Sample & Sensor & $\begin{array}{l}\text { Range of } \\
\text { Dynamic }\end{array}$ & $\begin{array}{c}\text { Limit of } \\
\text { Detection }\end{array}$ & Ref. \\
\hline 1. & $\begin{array}{l}\text { Clonidine } \mathrm{HCl} \\
\text { tablets in } \\
\text { pharmaceutical } \\
\text { formulations }\end{array}$ & $\begin{array}{l}\text { PVC membrane } \\
30 \% \text {, DBP } 62 \% \text {, ion } \\
\text { pair } 6 \% \text { and ionic } \\
\text { liquid } 2 \% \text {. }\end{array}$ & $\begin{array}{l}7,0 \times 10^{-6}-1,0 \times \\
10^{-2} \mathrm{M}\end{array}$ & $\begin{array}{l}6,5 \times 10^{-6} \mathrm{M} \text {, } \\
\text { Response time: } 10 \\
\text { seconds }\end{array}$ & {$[10]$} \\
\hline 2. & $\begin{array}{l}\text { Clonidine } \mathrm{HCl} \\
\text { tablets in } \\
\text { pharmaceutical } \\
\text { preparations }\end{array}$ & $\begin{array}{l}\text { Sensor 1: } \\
\text { Cyclodextrin } \\
\text { membrane } \\
\text { Sensor 2: PVC o- } \\
\text { nitrophenyl octyl } \\
\text { ether (o-NPOE) as a } \\
\text { plasticizer. }\end{array}$ & $\begin{array}{l}\text { Sensor } 1 \text { : } \\
1 \times 10^{-2}-6.0 \times \\
10^{-6} \mathrm{M} \\
\text { Sensor } 2 \text { : } \\
1 \times 10^{-2}-5.5 \times \\
10^{-6} \mathrm{M}\end{array}$ & $\begin{array}{l}\text { Sensor 1: } \\
5 \times 10^{-6} \mathrm{M} \\
\text { Sensor } 2: 3.5 \times 10- \\
6 \mathrm{M} \text {, in pH range } \\
2-7 \text {. }\end{array}$ & [11] \\
\hline
\end{tabular}

Clonidine determination has also been developed using a PVC membrane potentiometric sensor in pharmaceutical formulations. The electrode response is based on the ion-exchange mechanism. The ion-pair used as a sensing element in the PVC membrane composition was synthesized through clonidine hydrochloride and tetraphenylborate. The PVC membrane sensor's best response was obtained from 30\% PVC membrane design, $62 \%$ DBP, $6 \%$ ion pair, and $2 \%$ ionic liquid. This method has been successfully applied in the determination of clonidine in several formulations. The sensor used shows a linear dynamic range between 7.0 $\times 10^{-6}-1.0 \times 10^{-2} \mathrm{M}$ of clonidine with a Nernstian $(58.3 \pm 0.4) \mathrm{mVdecade}-1$ slope, and the detection limit is 6.5 $\times 10^{-6} \mathrm{M}$. The electrodes used achieved a fast response time of about 10 seconds, and service life of about six weeks without a significant change in performance [10].

Potentiometric methods have also been developed for the determination of clonidine $\mathrm{HCl}$ levels in pharmaceutical preparations. Two new membrane sensors with a cylindrical configuration for clonidine $\mathrm{HCl}$ were used. Sensors 1 and 2 were made using cyclodextrins in the presence of potassium tetrakis (4chlorophenyl) borate (KTpClPB) as an ion additive, PVC as a matrix, and o-nitrophenyl octyl ether (o-NPOE) as a plasticizer. Both sensors show a significant response to clonidine. A cationic slope close to Nernstian 53 and $54 \mathrm{mV} /$ decade over a relatively wide dynamic range, for sensor one around $1 \times 10^{-2}-6.0 \times 10^{-6}$ and sensor two around $1 \times 10^{-2}-5.5 \times 10^{-6} \mathrm{M}$. The detection limits observed were approximately $5 \times 10^{-6}$ for sensor 1 and $3.5 \times 10^{-6} \mathrm{M}$ for sensor 2 in the $\mathrm{pH}$ range 2-7. The sensor developed using the new ionophore increases the selectivity for clonidine in the presence of different ions. Clonidine determination of $230.09 \mathrm{~g} / \mathrm{mL}$ showed good accuracy and precision (101.99 and $10.89 \%$ and 2.77 and $3.36 \%$, respectively) for the $\beta$ - and $-\mathrm{CD}$ sensors. The sensors studied were linked to determine clonidine in dosage form and compared with those obtained using the HPLC technique. The sensor has been used as a pointer sensor for clonidine determination by potentiometric titration. The studied sensors revealed good analytical characteristics, high selectivity, fast response, long life, good stability with high accuracy and precision [11].

\subsection{High-performance liquid chromatography (HPLC) analysis}

Some of the high-performance liquid chromatography methods that have been used quantitatively to analyze clonidine levels in raw materials, mixtures, and pharmaceutical preparations are summarized as follows (Table 4). 


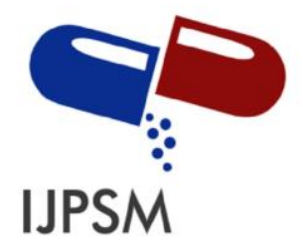

Rahma Yuni Safitri et al, Int. Journal of Pharmaceutical Sciences and Medicine (IJPSM),

Vol.6 Issue. 4, April- 2021, pg. 12-24

ISSN: 2519-9889

Impact Factor: 3.426

Table 4: Clonidine analysis using HPLC

\begin{tabular}{|c|c|c|c|c|c|c|}
\hline No. & Sample & Column & Mobile phase & Detector & $\begin{array}{l}\text { Chromatographic } \\
\text { Condition }\end{array}$ & Ref. \\
\hline 1. & $\begin{array}{l}\text { Simultaneous } \\
\text { tablets of } \\
\text { clonidine } \mathrm{HCl} \\
\text { in } \\
\text { pharmaceutical } \\
\text { formulations }\end{array}$ & $\begin{array}{l}\text { Column C18 } \\
(1.7 \mathrm{~m} 2.1 \times 50 \\
\mathrm{mm}) \text { is heated } \\
\text { at } 50^{\circ} \mathrm{C} \text {. }\end{array}$ & $\begin{array}{l}\text { Sodium } \\
\text { chloride: } \\
\text { hydrochloric } \\
\text { acid (95: 5) }\end{array}$ & $\begin{array}{c}\text { UV } \\
(201 \mathrm{~nm})\end{array}$ & $\begin{array}{l}\text { Flow rate: } 0,5 \\
\mathrm{~mL} / \mathrm{min}\end{array}$ & {$[12]$} \\
\hline 2. & $\begin{array}{l}\text { Clonidine } \mathrm{HCl} \\
\text { tablets in an } \\
\text { oral liquid } \\
\text { formulation }\end{array}$ & $\begin{array}{l}\text { Zorbax Eclipse } \\
\text { XDB-C8 }(4,6 \mathrm{x} \\
150 \mathrm{~mm}, 5 \mathrm{~mm}) \\
\text { (AgilentVR, } \\
\text { AS). }\end{array}$ & $\begin{array}{l}\text { Sodium 1-octane } \\
\text { sulfonic: } \\
\text { orthophosphoric } \\
\text { acid, with a pH } \\
\text { of } 3\end{array}$ & $\begin{array}{c}\text { UV } \\
(220 \mathrm{~nm})\end{array}$ & $\begin{array}{l}\text { Flow rate: } 1,5 \\
\mathrm{~mL} / \mathrm{min}\end{array}$ & [13] \\
\hline 3. & $\begin{array}{l}\text { Simultaneous } \\
\text { tablets of } \\
\text { clonidine } \mathrm{HCl} \text {, } \\
\text { ketamine } \mathrm{HCl} \text {, } \\
\text { gabapentin, and } \\
\text { baclofen in a } \\
\text { paint } \\
\text { formulation }\end{array}$ & $\begin{array}{l}\text { Phenomenex } \\
\text { Gemini C18 (50 } \\
\mathrm{mm} \times 3,0 \mathrm{~mm} \text {, } \\
3 \mu \mathrm{m})\end{array}$ & $\begin{array}{l}0.04 \% \\
\text { ammonium } \\
\text { acetate in } \\
\mathrm{ddH}_{2} \mathrm{O}, \mathrm{pH} 5.5 \text {, } \\
\text { and methanol }\end{array}$ & $\begin{array}{c}\text { MS- } \\
\text { ESI/UV } \\
(202 \mathrm{~nm}) \\
(220 \mathrm{~nm})\end{array}$ & $\begin{array}{l}\text { Flow rate: } 0,4 \\
\mathrm{~mL} / \mathrm{min}\end{array}$ & [14] \\
\hline 4. & $\begin{array}{l}\text { Clonidine } \\
\text { tablets in } \\
\text { environmental } \\
\text { water samples }\end{array}$ & $\begin{array}{l}\text { Shimadzu }(2.1 \\
\times 150 \mathrm{~mm}, 5 \\
\mu \mathrm{m})\end{array}$ & $\begin{array}{l}97 \% \text { ACN with } \\
3 \% \text { buffer water } \\
\text { containing } 50 \\
\text { mM ammonium } \\
\text { acetate at pH } 3.0\end{array}$ & MS-ESI & $\begin{array}{l}\text { Fl ow rate: } 0,2 \\
\mathrm{~mL} / \mathrm{min}\end{array}$ & {$[15]$} \\
\hline 5. & $\begin{array}{l}\text { Simultaneous } \\
\text { tablets of } \\
\text { clonidine } \mathrm{HCl} \\
\text { and } \\
\text { chlorthalidone } \\
\text { in a combined } \\
\text { dosage form }\end{array}$ & $\begin{array}{l}\text { Column C18 } \\
(250 \mathrm{~mm} \times 4,6 \\
\mathrm{mm} \times 2,6 \mu \mathrm{m})\end{array}$ & $\begin{array}{l}\text { Buffer (pH 4.0) } \\
\text { : Methanol } \\
(70: 30)\end{array}$ & $\begin{array}{c}\text { UV } \\
(220 \mathrm{~nm})\end{array}$ & Flow rate: $1 \mathrm{~mL} / \mathrm{min}$ & [16] \\
\hline 6. & $\begin{array}{l}\text { Clonidine } \mathrm{HCl} \\
\text { tablets in } \\
\text { routine } \\
\text { inspection } \\
\text { analysis }\end{array}$ & $\begin{array}{l}\text { Ultimate TM } \\
\text { C18 }(4.6 \times 25 \\
\mathrm{cm})\end{array}$ & $\begin{array}{l}\text { a mixture of } \\
\text { methanol, } \\
\text { acetonitrile, and } \\
20 \mathrm{mM} \\
\text { formatted } \\
\text { ammonium } \\
\text { buffer (pH 3,2) }\end{array}$ & MS-ESI & Not available & [17] \\
\hline 7. & $\begin{array}{l}\text { Simultaneous } \\
\text { tablets of } \\
\text { clonidine } \mathrm{HCl} \\
\text { and } \\
\text { hydrochlorothi } \\
\text { azide in raw } \\
\text { materials and }\end{array}$ & $\begin{array}{l}\text { XTerra C18 } \\
(150 \mathrm{~mm} \times 4.6 \\
\text { mm i.d., } 3,5 \\
\mu \mathrm{m})\end{array}$ & $\begin{array}{l}\text { Buffer: } \\
\text { Acetonitrile (55: } \\
45 \mathrm{v} / \mathrm{v}]\end{array}$ & $\begin{array}{c}\text { UV } \\
(254 \mathrm{~nm})\end{array}$ & $\begin{array}{l}\text { Flow rate: } 0,6 \\
\mathrm{~mL} / \mathrm{min}\end{array}$ & [18] \\
\hline
\end{tabular}




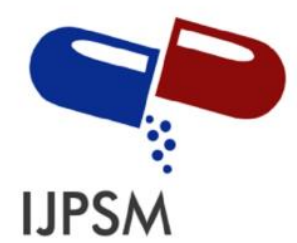

Rahma Yuni Safitri et al, Int. Journal of Pharmaceutical Sciences and Medicine (IJPSM), Vol.6 Issue. 4, April- 2021, pg. 12-24

ISSN: 2519-9889 Impact Factor: 3.426

\begin{tabular}{|c|c|c|c|c|c|c|}
\hline & $\begin{array}{l}\text { pharmaceutical } \\
\text { preparations }\end{array}$ & & & & & \\
\hline 8. & $\begin{array}{l}\text { Clonidine } \mathrm{HCl} \\
\text { tablets in an } \\
\text { oral liquid } \\
\text { formulation }\end{array}$ & $\begin{array}{l}\text { Shimadzu LC20 } \\
\text { sistem, } \\
(150 \mathrm{~mm} \times 4.6 \\
\mathrm{mm} \mathrm{C} 18 \text { ODS- } \\
35 \mu \mathrm{m})\end{array}$ & $\begin{array}{l}\text { Acetonitrile and } \\
\text { ammonium } \\
\text { acetate }(10 \mathrm{mM} \text {, } \\
\text { pH } 7.8 \pm 0.04 \text { in } \\
\text { increments of } 1 \\
\text { M potassium } \\
\text { hydroxide }) \\
45: 55(\mathrm{v} / \mathrm{v})\end{array}$ & $\begin{array}{c}\text { UV } \\
(230 \mathrm{~nm})\end{array}$ & $\begin{array}{l}\text { Flow rate: } 1,0 \\
\mathrm{~mL} / \mathrm{min}\end{array}$ & [19] \\
\hline 9. & $\begin{array}{l}\text { Clonidine } \mathrm{HCl} \\
\text { tablets in a } \\
\text { serum analyte } \\
\text { formulation }\end{array}$ & $\begin{array}{l}\text { Shim-pack XR- } \\
\text { ODS C18 (150 } \\
\mathrm{mm} \times 4.6 \mathrm{~mm} \text {, } \\
5 \mu \mathrm{m})\end{array}$ & $\begin{array}{l}\text { Phase A consists } \\
\text { of } 0.01 \text { mol L- } \\
1 \text { buffer format } \\
\text { ammonium } \\
\text { (pH = 5.0); } \\
\text { phase B consists } \\
\text { of acetonitrile: } \\
\text { isopropyl } \\
\text { alcohol: pure } \\
\text { water (75:15:10, } \\
\text { v: v: v), and } \\
\text { phase C consists } \\
\text { of methanol: } \\
\text { ammmmonium } \\
\text { buffer format } \\
0.01 \text { mol L }-1 \\
(\mathrm{pH}=5.0) \\
(90: 10, \mathrm{v}: \mathrm{v})\end{array}$ & $\begin{array}{c}\mathrm{UV} \\
(255 \mathrm{~nm})\end{array}$ & $\begin{array}{l}\text { Flow rate: } 0,4 \\
\mathrm{~mL} / \mathrm{min}\end{array}$ & [20] \\
\hline 10. & $\begin{array}{l}\text { Clonidine } \mathrm{HCl} \\
\text { tablets in the } \\
\text { formulation } \\
\text { raw material }\end{array}$ & $\begin{array}{l}\text { Prontosil } 120-5 \\
\text { C18 AQ, with a } \\
\text { size of } 5 \mu \mathrm{m}\end{array}$ & $\begin{array}{l}\text { Acetonitrile- } \\
\text { buffer (2:98) }\end{array}$ & $\begin{array}{c}\text { UV } \\
(240 \mathrm{~nm})\end{array}$ & $\begin{array}{l}\text { Flow rate: } 100 \\
\mathrm{~mL} / \mathrm{min} \\
\text { Temperature: } 37- \\
40^{\circ} \mathrm{C}\end{array}$ & [21] \\
\hline 11. & $\begin{array}{l}\text { Clonidine } \mathrm{HCl} \\
\text { and } \\
\text { chlorthalidone } \\
\text { in the raw } \\
\text { material for } \\
\text { tablet } \\
\text { formulations }\end{array}$ & $\begin{array}{l}\text { Zorbax Eclipse } \\
\text { XDB-C18 }(4.6 \\
\text { x } 250 \mathrm{~mm} \text { x } \\
5 \mu \mathrm{m})\end{array}$ & $\begin{array}{l}\text { Methanol-Ortho } \\
\text { Phosphoric Acid } \\
(50: 50 \mathrm{v} / \mathrm{v})\end{array}$ & $\begin{array}{c}\text { UV } \\
(236 \mathrm{~nm})\end{array}$ & $\begin{array}{l}\text { Flow rate: } 1,0 \\
\mathrm{~mL} / \mathrm{min}\end{array}$ & [22] \\
\hline 12. & $\begin{array}{l}\text { Simultaneous } \\
\text { tablets of } \\
\text { clonidine } \mathrm{HCl} \\
\text { and morphine } \\
\text { in the drug } \\
\text { release profile }\end{array}$ & $\begin{array}{l}\text { Hypersil - ODS } \\
(53 \mathrm{~mm} \times 6,6 \\
\mathrm{mm} \times 5.05 \mu \mathrm{m})\end{array}$ & $\begin{array}{l}10 \mathrm{mM} \text { diluted } \\
\text { sodium dodecyl } \\
\text { sulfate } \\
\text { acetonitrile with } \\
\text { phosphoric acid } \\
(60: 40 \mathrm{v} / \mathrm{v}) \\
\text { with pH } 3\end{array}$ & $\begin{array}{c}\text { UV } \\
(214 \mathrm{~nm})\end{array}$ & Flow rate: $1 \mathrm{~mL} / \mathrm{min}$ & [23] \\
\hline 13. & $\begin{array}{l}\text { Clonidine } \mathrm{HCl} \\
\text { tablets in the } \\
\text { formulation }\end{array}$ & $\begin{array}{l}\text { Cohesive } \\
\text { Propel C18 (5 } \\
\mu \mathrm{m} \times 3.0 \times 50 \\
\mathrm{~mm})\end{array}$ & $\begin{array}{l}\text { Mixed mobile } \\
\text { phase from } \\
\text { 80:20 (50:50 } \\
\text { methanol: }\end{array}$ & MS-ESI & $\begin{array}{l}\text { Flow rate: } 0,35 \\
\mathrm{~mL} / \mathrm{min}\end{array}$ & [24] \\
\hline
\end{tabular}




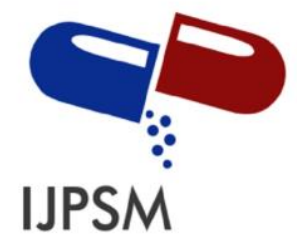

Rahma Yuni Safitri et al, Int. Journal of Pharmaceutical Sciences and Medicine (IJPSM), Vol.6 Issue. 4, April- 2021, pg. 12-24

ISSN: 2519-9889

Impact Factor: 3.426

\begin{tabular}{|l|l|l|l|l|l|l|}
\hline & & & $\begin{array}{l}\text { acetonitrile): } 10 \\
\text { mM ammonium } \\
\text { acetate. With a } \\
\text { pH of 6.8 }\end{array}$ & & & \\
\hline 14. & $\begin{array}{l}\text { Clonidine } \mathrm{HCl} \\
\text { tablets in an } \\
\text { oral liquid } \\
\text { formulation }\end{array}$ & $\begin{array}{l}\text { Zorbax SB-C3 } \\
(150 \mathrm{~mm} \times 3.0\end{array}$ & $\begin{array}{l}\text { Phosphoric acid: } \\
\text { acetonitrile } \\
(25: 75 \mathrm{v} / \mathrm{v}) \text { with }\end{array}$ & $\begin{array}{l}\text { UV } \\
\text { a } \mathrm{pH} \text { of } 4.0\end{array}$ & $\begin{array}{l}\text { Flow rate: } 1,5 \\
\mathrm{~mL} / \mathrm{min}\end{array}$ & [25] \\
& & & \\
\hline
\end{tabular}

The determination of clonidine levels in tablets is carried out as follows. A total of 20 tablets were weighed and powdered, then weighed a powder equivalent to $0.1 \mathrm{mg}$ of clonidine hydrochloride put into a $100 \mathrm{ml}$ measuring flask, added $60 \mathrm{ml}$ of methanol $\mathrm{P}$ to mark. Centrifuge a portion of the solution at $3500 \mathrm{rpm}$ for 15 minutes and inject the liquid into the chromatograph. The high-performance liquid chromatograph is equipped with a $220 \mathrm{~nm}$ detector and a $4.6 \mathrm{~mm} \times 15 \mathrm{~cm}$ column containing an $\mathrm{L} 7$ filler. Flow rate approx. $1.5 \mathrm{~mL}$ per minute. The relative retention times of clonidine and 2,6-dichloroaniline were approximately 0.5 and 1.0 , respectively, and the number of theoretical plates at the clonidine peak was not less than 3500 . The relative standard deviation of re-injection was not more than 2.0\%. Procedure: Calculate the amount in $\mathrm{mg}$, clonidine hydrochloride, $\mathrm{C}_{9} \mathrm{H}_{9} \mathrm{Cl}_{2} \mathrm{~N}_{3} \cdot \mathrm{HCl}$, in tablet powder used with the formula:

$$
0.1 \mathrm{C}=(\mathrm{ru}: \mathrm{rs})
$$

$\mathrm{C}$ is the BPFI clonidine hydrochloride content in $\mu \mathrm{g}$ per $\mathrm{mL}$ of standard solution; ru and rs are the test solution's peak responses and standard solution [2].

Clonidine analysis in several tablets was carried out simultaneously. Several methods that are fast, simple, selective, and accurate are referred to as HPLC. Separation was carried out using a C18 column $(1.7 \mathrm{~m} 2.1 \times$ $50 \mathrm{~mm}$ ) heated at $50^{\circ} \mathrm{C}$. The mobile phase used is a mixture of sodium chloride: hydrochloric acid (95: 5). Separation was observed at a flow rate of $0.5 \mathrm{~mL} / \mathrm{min}$, using a UV detector observed at $201 \mathrm{~nm}$. According to the International Conference on Harmonization guidelines, the chromatographic method has been developed and validated for securing the production process [12].

Analysis by chromatography (HPLC) method is for determining clonidine levels (CLD) in an oral liquid formulation. Separation was performed using a Zorbax Eclipse XDB-C8 $(4.6 \mathrm{~mm}$ x $150 \mathrm{~mm}, 5 \mathrm{~mm})$ column (Agilent VR, US). The temperature used is $25^{\circ} \mathrm{C}$ followed by a mobile phase, namely sodium octane-1sulfonic: orthophosphoric acid with a $\mathrm{pH}$ of 3 , observed at a flow rate of about $1.5 \mathrm{~mL} / \mathrm{min}$, using a UV detector observed at $220 \mathrm{~nm}$. A system suitability test was performed on each day of analysis, and after acceptance criteria had been approved, clonidine samples were analyzed. The system suitability solution consisted of $2 \mu \mathrm{g} / \mathrm{mL}$ of clonidine hydrochloride and $2.4 \mu \mathrm{g} / \mathrm{mL}$ of 2,6-dichloroaniline. Chromatographic parameters monitored over several days of analysis included column efficiency (USP acceptance limit:> 3500 theoretical plates), tailings factor (USP acceptance limit: <1.5), and relative retention times $(0.5$ for clonidine and 1.0 for clonidine 2,6-dichloroaniline) [13].

In this study, a liquid chromatograph-tandem mass spectrometry (LC-MS / MS) method was developed and validated to identify and quantify four drugs with percutaneous absorption in the paint formulation using the finite dose model. These four drugs include ketamine $\mathrm{HCl}$, gabapentin, clonidine $\mathrm{HCl}$, and baclofen. The mobile phase used in the separation consisted of $0.04 \%$ ammonium acetate in $\operatorname{ddH} 2 \mathrm{O}, \mathrm{pH} 5.5$, and methanol. Chromatographic separation was carried out on a Phenomenex Gemini C18 column (50 mm x $3.0 \mathrm{~mm}, 3 \mu \mathrm{m})$. With a flow rate of $0.4 \mathrm{~mL} /$ minute. The analyte system was detected using a positive ionization (ESI +) electrospray mode. It can also be measured with a UV detector at $202 \mathrm{~nm}$ and $220 \mathrm{~nm}$. The newly developed method has been validated for intra-day and inter-day accuracy, precision, selectivity, and sensitivity. The experimental results show that the newly developed method can be applied to transdermal pharmaceutical pain formulations [14].

Reverse-phase chromatography is the most common separation method for small molecule drugs. However, polar drugs may have poor retention and peak form reverse-phase high-performance liquid chromatography 


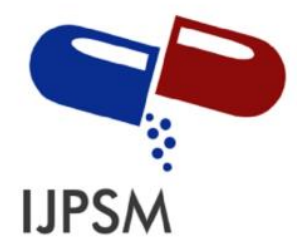

\section{Rahma Yuni Safitri et al, Int. Journal of Pharmaceutical Sciences and Medicine (IJPSM), Vol.6 Issue. 4, April- 2021, pg. 12-24}

ISSN: 2519-9889

Impact Factor: 3.426

(RP-HPLC). Hydrophilic interaction liquid chromatography (HILIC) provides a viable alternative to RP-HPLC and the best way to separate polar compounds. This paper describes HILIC/ESI-MS/MS. Separation was carried out using a Shimadzu column $(2.1 \times 150 \mathrm{~mm}, 5 \mu \mathrm{m})$. The best separation conditions of $97 \%$ ACN with $3 \%$ water buffer containing $50 \mathrm{mM}$ ammonium acetate at $\mathrm{pH} 3.0$ were obtained by two optimization methods, with a flow rate of $0.2 \mathrm{~mL} / \mathrm{min}$. Analyte detection was carried out in positive ionization (ESI+) electrospray mode. The ACN content in the cellular phase contributes most significantly to separation. Also, sample diluent and junction volume were found to affect chromatographic performance. To match the LC mobile phase to hydrophilic interactions, an appropriate sample pretreatment method, salting-out-liquid-liquid extraction, in which ACN was chosen as the extractant. The optimal extraction parameters for salting-out fluids are as follows: $400 \mathrm{~L} \mathrm{ACN}$ is added to $1 \mathrm{ml}$ of the sample solution containing $500 \mathrm{mg}$ of $\mathrm{NH}_{4} \mathrm{Cl}$ at $\mathrm{pH}$ 14.0. The linearity ranges from 0.01 to $1.00 \mu \mathrm{g} / \mathrm{mL}$ with $\mathrm{r} 2>0.9937$. LOD ranges between 1.9 and $2.5 \mathrm{ng} / \mathrm{mL}$. The developed method is applied to environmental water samples with good performance [15].

The reverse-phase high-performance liquid chromatography method was developed for the simultaneous determination of clonidine $\mathrm{HCl}$ and chlorthalidone. This method was developed in the form of a combined dose. Separation was accomplished by LC-20 using column C18 (250 mm x $4.6 \mathrm{~mm}$ x $2.6 \mu \mathrm{m})$ and buffer (pH 4.0): methanol (70:30) as the mobile phase, at a flow rate of $1 \mathrm{~mL} / \mathrm{minute}$. The detection was carried out at 220 $\mathrm{nm}$. The retention times of clonidine $\mathrm{HCl}$ and chlorthalidone were 5.980 minutes and 4.150 minutes, respectively. The method has been validated for linearity, accuracy, and precision. Linearity was observed for clonidine $\mathrm{HCl} 1.5-4.5 \mu \mathrm{g} / \mathrm{mL}$ and chlorthalidone $60-180 \mu \mathrm{g} / \mathrm{mL}$. The percent recoveries obtained for clonidine $\mathrm{HCl}$ and chlorthalidone were in the range of 99.56-101.02 and 99.11-100.88\%. The method developed is entirely accurate, precise, and fast for the simultaneous determination of clonidine $\mathrm{HCl}$ and chlorthalidone levels in their combined dosage form [16].

The sensitive and specific liquid chromatography-electrospray ionization mass spectrometry method (LC/ESI/MS) was developed to analyze 18 drugs used to treat anti-hypertension, including diuretics, calcium antagonists, and angiogenesis-converting enzyme inhibitors (ACEI) as contaminants in dietary supplements and traditional Chinese medicine. Separation was carried out on an Xtimate TM C18 reverse phase column using a mixture of methanol, acetonitrile, and $20 \mathrm{mM}$ ammonium buffer format ( $\mathrm{pH} 3.2$ ) as the mobile phase. This method shows linearity from 0.03 to $21.52 \mathrm{mg} \mathrm{kg}^{-1}$. The detection limit ranged from 6.5 to $86.0 \mu \mathrm{g} \mathrm{kg}^{-1}$. Sample recovery ranged from $71 \%$ to $109 \%$. The procedure was successfully applied in routine inspection analysis [17].

The new RP-HPLC method is precise, sensitive, and accurate for simultaneous clonidine and hydrochlorothiazide estimation in bulk and tablets. The two drugs' resolution was achieved on the XTerra C18 column $(150 \mathrm{~mm} \times 4.6 \mathrm{~mm} \times 3.5 \mu \mathrm{m})$ with UV detection at $254 \mathrm{~nm}$ and the mobile phase consisting of Buffer and Acetonitrile (55: $45 \mathrm{v} / \mathrm{v})$. Clonidine and hydrochlorothiazide produced good peaks. Mean retention times is of 2.669 and 3.855 minutes. Linearity response ( $>0.999$ ) was observed in the range of $20-60 \mu \mathrm{g} / \mathrm{mL}$ for clonidine and $50-150 \mu \mathrm{g} / \mathrm{mL}$ for hydrochlorothiazide. The lower limit of quantification and lower detection limits was 9.95 and 2.95 for clonidine and 9.91 and 2.97 for hydrochlorothiazide. Parameter validation was carried out according to ICH guidelines, and the proposed method could be useful in routine analysis for the determination of clonidine and hydrochlorothiazide in pharmaceutical dosage forms [18].

This article describes the development and validation of a stable pediatric oral formulation of clonidine hydrochloride $50 \mu \mathrm{g} / \mathrm{mL}$, individualized pediatric dosing. The stability of the spontaneously prepared clonidine hydrochloride formulation was assessed using a validated HPLC method. Separation was carried out using a Shimadzu LC20 column sized (150 mm x $4.6 \mathrm{~mm} \mathrm{C} 18$ ODS-3), using a mobile phase consisting of acetonitrile and ammonium acetate $(45: 55) \mathrm{v} / \mathrm{v}$ with the addition of $1 \mathrm{M}$ potassium hydroxide. The analyte was detected at $230 \mathrm{~nm}$ with a flow rate of $1.0 \mathrm{~mL} /$ minute. Clonidine hydrochloride is stable in aqueous buffer solutions at room temperature for up to 9 months. The formulation described is chemically stable for at least nine months when stored in a $100 \mathrm{ml}$ brown PET bottle at room temperature, enabling adequate oral treatment in pediatric patients [19].

Simultaneous determinations of 5 antihypertensive drugs were calculated using ultra-high-performance liquid chromatography - heated electrospray ionization - tandem mass spectrometry (UHPLC-MS/MS) in serum 


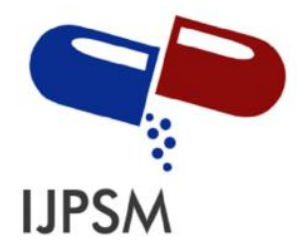

\section{Rahma Yuni Safitri et al, Int. Journal of Pharmaceutical Sciences and Medicine (IJPSM), Vol.6 Issue. 4, April- 2021, pg. 12-24}

ISSN: 2519-9889

Impact Factor: 3.426

analyte formulations. The untreated samples were directly analyzed in a column diversion system using an extraction column packed with limited access carbon nanotubes (RACNT) in an ultra-high performance liquid chromatography coupled to a mass spectrometer (UHPLC-MS/MS). This method was validated according to Food and Drug Administration (FDA) guidelines, linearity for all analytes specified within the respective analytic ranges (coefficient of determination higher than 0.99) with limits of detection (LOD) and quantification (LOQ) ranging from 0.09 to $10.85 \mu \mathrm{g} \mathrm{L} \mathrm{L}^{-1}$ and from 0.30 to $36.17 \mu \mathrm{g} \mathrm{L}^{-1}$, respectively. The recovery values were $(88-112 \%)$ with relevant results for inter-and intra-day accuracy and precision. The method provides an analytical frequency of 5 samples per hour, including sample preparation and separation/detection steps. The validated method was successfully used to analyze samples from patients undergoing treatment with antihypertensive drugs, which helps pharmacometabolomic, pharmacogenomic, and pharmacokinetic studies [20].

A high-performance liquid chromatography (HPLC) method has been developed and validated to determine clonidine in the raw material for tablet formulations. In HPLC, clonidine uses acetonitrile-buffer (2:98) as the mobile phase with a $100 \mathrm{~mL} /$ minute flow rate at $37-20^{\circ} \mathrm{C}$. The separation was carried out on a $120-5 \mathrm{C} 18 \mathrm{AQ}$, $5 \mu \mathrm{m}$ loss column, equipped with a UV detector at $240 \mathrm{~nm}$. This method has been successfully applied to pharmaceutical preparation formulations because there were no chromatographic abnormalities of tablet excipients. The linearity observed was $5-25 \mu \mathrm{g} / \mathrm{mL}$. The method developed was accurate, precise, and fast for estimating clonidine $\mathrm{HCl}$. The development of quantitative determination of clonidine hydrochloride by HPLC in model solutions using various drug concentrations has been carried out. The clonidine hydrochloride content is determined according to the equation $\mathrm{S}=0.5 \cdot 10^{-4} \mathrm{C}+1.8 \cdot 10^{-3}$; the correlation coefficient is 0.9964 . It is known that the relative uncertainty of the mean yield does not exceed $\pm 2.12 \%$ when the HPLC analysis of clonidine hydrochloride is in the model solution. Identification and quantification of clonidine hydrochloride by the integrated HPLC method makes it possible to obtain reliable and reproducible research results. The HPLC method can be recommended for application in the practice of forensic bureaus, toxicology centers, clinical laboratories for drug studies on biological objects [21].

A high-performance liquid chromatography (HPLC) method has been developed and validated for the simultaneous determination of clonidine $\mathrm{HCl}$ with chlorthalidone in the raw material for tablet formulations. In HPLC, methanol: phosphoric acid (50: 50) v/v is used as the mobile phase with a $1 \mathrm{~mL} / \mathrm{minute}$ flow rate at room temperature. Separation was carried out on a Zorbax Eclipse XDB-C18 column, equipped with a UV detector at $236 \mathrm{~nm}$. The retention time between clonidine $\mathrm{HCl}$ and chlorthalidone is 2.510 minutes and 3.403 minutes. This method has been successfully applied to pharmaceutical formulations because there are no chromatographic abnormalities of tablet excipients. The linearity observed was $5-25 \mu \mathrm{g} / \mathrm{mL}$. The method developed was accurate, precise, and fast for estimating clonidine $\mathrm{HCl}$ and chlorthalidone in mixed laboratories [22].

The determination of the clonidine level in this article was carried out in conjunction with the morphine in the vaginal pessaries of the drug release profile using the isocratic reverse-phase high-performance liquid chromatography (HPLC) method. Separation was performed using a Hypersil - ODS column measuring (53mm x $6.6 \mathrm{~mm}$ x 5.0 micron). $10 \mathrm{mM}$ dilute sodium dodecyl sulfate acetonitrile with phosphoric acid (60:40 $\mathrm{v} / \mathrm{v}$ ) was used as the mobile phase with a $\mathrm{pH}$ of 3 . The flow rate is $1 \mathrm{~mL} /$ minute. Samples were detected using a UV detector at $214 \mathrm{~nm}$. Retention times achieved for morphine and clonidine were 1.5 minutes and 3.3 minutes, respectively. Linearity, precision, range, quantization, and limit of detection are assessed. The calibration curve was made linear over a concentration range of $19-465 \mu \mathrm{g}-\mathrm{mL}^{-1}$ for morphine and $0.12-2.91$ $\mu \mathrm{g}-\mathrm{mL}^{-1}$ for clonidine. A rapidly developed, simple method is applied to determine morphine and clonidine in vaginal pessaries evaluating the drug release profile. It can be concluded that both drugs were released at $80 \%$ of the initial amount introduced into the pessaries within 35 minutes. Morphine is released much faster than clonidine reaching stable concentrations in less than 15 minutes [23].

Analysis by specific, sensitive, and precise liquid chromatography methods using LC-MS determines clonidine in tablet formulation. This article describes a specific and sensitive LC-MS / MS method for the test formulation of clonidine hydrochloride tablets at a dosage of $0.3 \mathrm{mg}$. This method was validated following USFDA guidelines and was applied to healthy adult male volunteers. Separation was carried out using a C18 


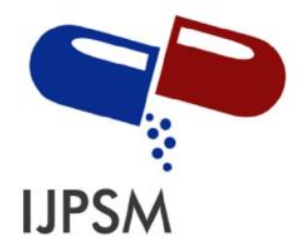

\author{
Rahma Yuni Safitri et al, Int. Journal of Pharmaceutical Sciences and Medicine (IJPSM), \\ Vol.6 Issue. 4, April- 2021, pg. 12-24
}

ISSN: 2519-9889

Impact Factor: 3.426

$(5 \mu \mathrm{m} \times 3.0 \times 50 \mathrm{~mm})$ Cohesive Propel column with an isocratic mobile phase composition, namely a mixture of 80:20 (50:50 methanol: acetonitrile): $10 \mathrm{mM}$ ammonium acetate with a $\mathrm{pH}$ of 6.8 . Analyte detection was carried out using the ionization electrospray system (ESI). With a flow rate of $0.35 \mathrm{~mL} / \mathrm{minute}$. In testing the clonidine $\mathrm{HCl}$ tablet formulation, pharmacokinetics such as Cmax, AUC, Tmax, and t1 / 2 were also observed using a non-compartmental model. The LC-MS / MS method can be considered helpful for further clinical studies to describe the pharmacokinetic aspects of determining bioavailability and drug bioequivalence [24].

This article describes the stability and validation of a stable pediatric oral formulation of clonidine hydrochloride $10 \mu \mathrm{g} / \mathrm{mL}$, individualized pediatric dosing. The strength of the spontaneously prepared clonidine hydrochloride formulation was assessed using a validated HPLC method. Separation was carried out using a Zorbax SB-C3 column sized (150 mm x $3.0 \mathrm{~mm}$ x $5 \mu \mathrm{m}$ ), using a mobile phase consisting of phosphoric acid and acetonitrile $(25: 75) \mathrm{v} / \mathrm{v}$ with the addition of $1 \mathrm{M}$ potassium hydroxide. The analyte was detected at $210 \mathrm{~nm}$ at a flow rate of $1.5 \mathrm{~mL} /$ minute. Clonidine hydrochloride is stable in a buffered aqueous solution at room temperature for 60 days. The concentration of clonidine determined using liquid chromatography has a specification between $95.0-105.05 \%$. After storage at a temperature of $2-8^{\circ} \mathrm{C}$ then added a preservative, namely potassium sorbate, about 90.0 and $110.0 \%$ of the initial concentration, with a pH between 4.4 and 4.7 , it can be concluded that there is no microbial growth. The stability of the clonidine hydrochloride oral solution in InorphaVR provides safe, easy, and efficient administration of pediatric patients. The LC method used is specific, linear, accurate, and precise and can be used for clinical studies to design an oral formulation of clonidine hydrochloride [25].

\title{
3.5 High-performance thin-layer chromatography (HPTLC) analysis
}

The High-Performance Thin Layer Chromatography (HPTLC) method had been used for the simultaneous quantitative analysis of clonidine $\mathrm{HCl}$ and hydrochlorothiazide. The high-performance thin-layer chromatography (HPTLC) analysis method has been developed and validated for the study of clonidine (CLD) and hydrochlorothiazide (HCT) in large quantities and tablet dosage forms. Separation was carried out on a 60G F254 silica gel plate with its mobile phase, namely Toluene: Ethanol: Ammonia (7.5: 2.5: 0.2 v/v). The detection was carried out at $207 \mathrm{~nm}$. The RF values obtained were 0.45 for clonidine hydrochloride and 0.23 for hydrochlorothiazide. The regression plots show an excellent linear relationship over a concentration range of 100-500 ng for clonidine hydrochloride and 60-300 ng for hydrochlorothiazide. Performing recoveries checked the accuracy, and the average recovery was $99,752 \%$ for clonidine hydrochloride and $99,663 \%$ for hydrochlorothiazide [26].

\section{Conclusion}

Overall, various analytical methods have been used to determine clonidine levels from 2010 to 2020. Determination of clonidine levels in the form of raw materials, mixtures, and pharmaceutical preparations has been carried out using various analytical methods, including spectrophotometry, potentiometry, highperformance liquid chromatography (HPLC), and high-performance thin-layer chromatography (HPTLC). Analysis using the HPLC technique is more often used in research because it can detect samples with concentrations very low to the nanogram level. The HPLC method, combined with mass spectrometry, has unique advantages and sensitivity in clonidine analysis in pharmaceutical preparations.

\section{References}

[1]. Sukandar EY, Andrajati R, Sigit JI, Adnyana IK, Setyadi AAP, Kusnandar. Iso Farmakoterapi. Jakarta: PT ISFI Penerbitan, 2008

[2]. Kementerian Kesehatan Republik Indonesia. Farmakope Indonesia Edisi VI. Jakarta: Kementerian Kesehatan Republik Indonesia; 2020.

[3]. Moffat AC, Osselton MD, Widdop B. Clarke's Analysis of Drugs and Poisons 4th Ed. London: Pharmaceutical Press, 2011. 


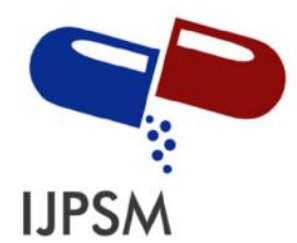

\section{Rahma Yuni Safitri et al, Int. Journal of Pharmaceutical Sciences and Medicine (IJPSM), Vol.6 Issue. 4, April- 2021, pg. 12-24}

[4]. American Society of Health-System Pharmacists. AHFS Drug Information ${ }^{\circledR}$ Essentials. Bethesda: American Society of Health-System ${ }^{\circledR}, 2011$.

[5]. Haggag RS, Belal SF, Shaalan RA. Selective stability-indicating methods for the determination of clonidine hydrochloride and/or its related substance, 2, 6-dichloroaniline. J. Food Drug Anal. 2011 Jun 1;19:174-82.

[6]. Kasture V, Patil P, Pawar S, Gudaghe V. Geometrical Correction Method for Estimation of Hydrochlorothiazide and Clonidine Hydrochloride from Biological Sample. Indo American J of Pharma. 2013;3(9):1592-600.

[7]. Khan HN, Asha C, Swarali M, Zameeruddin M, Bharkad VB. Development and Validation of Area under curve Method for the Estimation of Clonidine $\mathrm{HCl}$ in the Bulk and Pharmaceutical dosage form. Analyst. $2018 \mathrm{Feb}$ 28;2(1):1.

[8]. Cordova A. Validated colorimetric assay of Clonidine Hydrochloride from pharmaceutical preparations. Iranian Journal of pharmaceutical research: IJPR. 2016;15(1):149.

[9]. Pailla NR, Kuthati B. Spectrophotometric determination of drugs and pharmaceuticals by using Folin-Ciocalteu reagent. 2020;7(1).

[10]. Ganjali MR, Karimi S, Shahtaheri SJ, Norouzi P. Determination of clonidine by potentiometry using PVC membrane electrode. Int. J. Electrochem. Sci. 2013 Feb 1;8(2):1999-2008.

[11]. AlRabiah H, Al-Majed A, Abounassif M, Mostafa GA. Two novel potentiometric sensors for determination of clonidine in some pharmaceutical formulation. Int. J. Electrochem. Sci. 2016 Aug 1;11(10).

[12]. Sorrieul J, Robert J, Gibory V, Collet M, Boutet M, Kieffer H, Folliard C, Dupoiron D, Devys C. Validated chromatographic method for the simultaneous determination of eight drugs (morphine, ropivacaine, bupivacaine, baclofen, clonidine, sufentanil, fentanyl and ziconotide) for intrathecal analgesia. InAnnales pharmaceutiques francaises 2018 May 1;76(3):201-209.

[13]. Merino-Bohórquez V, Delgado-Valverde M, García-Palomo M, Dávila-Pousa MC, Cañete C, Villaronga M, Rodriguez-Marrodán B, López-Rojas R, Cameán-Fernández M, Pharmaceutical Technology Working Group and Pediatric Pharmacy Working Group of the Spanish Society of Hospital Pharmacy (SEFH). Physicochemical and microbiological stability of two new oral liquid formulations of clonidine hydrochloride for pediatric patients. Pharmaceutical development and technology. 2019 Apr 21;24(4):465-78.

[14]. Bassani AS, Banov D. Evaluation of the percutaneous absorption of ketamine $\mathrm{HCl}$, gabapentin, clonidine $\mathrm{HCl}$, and baclofen, in compounded transdermal pain formulations, using the Franz finite dose model. Pain Medicine. 2016 Feb $1 ; 17(2): 230-8$.

[15]. Wang Q, Yin CR, Xu L. Optimization of hydrophilic interaction LC by univariate and multivariate methods and its combination with salting- out liquid-liquid extraction for the determination of antihypertensive drugs in the environmental waters. Journal of separation science. 2013 Mar;36(6):1007-14.

[16]. Rohan SP, Divya T, Mandev BP. Development and Validation of Analytical Methods for Simultaneous Estimation of Clonidine $\mathrm{HCl}$ and Chlorthalidone in Their Combined Dosage Forms. J Pharm Sci Bioscientific Res. 2015; 5(5):463469.

[17]. Lu YL, Zhou NL, Liao SY, Su N, He DX, Tian QQ, Chen B, Yao SZ. Detection of adulteration of anti-hypertension dietary supplements and traditional Chinese medicines with synthetic drugs using LC/MS. Food Additives and Contaminants. 2010 Jul 1;27(7):893-902.

[18]. Kamepalli S, D Gowri S, Konda A, O.Bala S. Simultaneous Estimation of Clonidine and Hydrochlorothiazide by Reverse Phase HPLC in Bulk and Pharmaceutical Dosage Form. International Journal of Chemical and Analytical Science. 2012; 3(7):1478-1480.

[19]. De Goede AL, Boedhram RR, Eckhardt M, Hanff LM, Koch BC, Vermaat CH, Vermes A. Development and validation of a paediatric oral formulation of clonidine hydrochloride. International Journal of pharmaceutics. 2012 Aug 20;433(1-2):119-20.

[20]. De Faria HD, Bueno CT, Krieger JE, Krieger EM, Pereira AC, Santos PC, Figueiredo EC. Online extraction of antihypertensive drugs and their metabolites from untreated human serum samples using restricted access carbon 


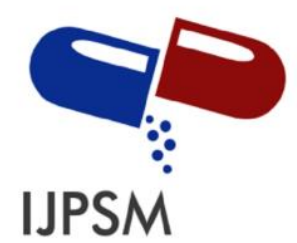

\section{Rahma Yuni Safitri et al, Int. Journal of Pharmaceutical Sciences and Medicine (IJPSM), Vol.6 Issue. 4, April- 2021, pg. 12-24}

ISSN: 2519-9889

Impact Factor: 3.426

nanotubes in a column switching liquid chromatography system. Journal of Chromatography A. 2017 Dec $15 ; 1528: 41-52$.

[21]. Mamina O, Kabachny V. Identification and quantitative determination of clonidine by HPLC method. ScienceRise: Pharmaceutical Science. 2020(5 (27)):30-6.

[22]. Hajera N. Khan et al. Development and Validation of RP-HPLC Method for Simultaneous Estimation of Clonidine $\mathrm{HCl}$ and Chlorthalidone in Bulk Form. 2017; 10(4).

[23]. Capra P, Marrubini G, Musitelli G, Pavanetto F, Perugini P. Development and Application of an Analytical Method for the Determination of Morphine and Clonidine in Vaginal Pessaries. International Journal of Pharmaceutical Analysis. 2014;1(39):2051-2740.

[24]. Savakula S, Pilli NR, Reddy SS. Bioequivalence and pharmacokinetic comparison between clonidine hydrochloride tablets $0.3 \mathrm{mg}$ : An open-label, balanced, randomized sequence, single-dose, two-period crossover study in healthy male volunteers. International Journal of Pharmaceutics and Drug Analysis. 2015 Sep 11:264-9.

[25]. Potier A, Voyage J, Nicolas A. Stability study of a clonidine oral solution in a novel vehicle designed for pediatric patients. Pharmaceutical development and technology. 2018 Nov 26;23(10):1067-76.

[26]. Teli MS, Sawant SS, Shukla S. Simultaneous Analysis of Clonidine HCl and Hydrochlorothiazide in Bulk and In Tablet By HPTLC With Uv Absorption. World Journal of Pharmacy and Pharmaceutical Sciences. 2016 Jan 8;5(3):975-82.

\section{A Brief Author Biography}

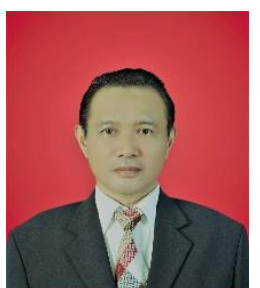

Prof. Dr. Harrizul Rivai, M.S., was born in Payakumbuh, West Sumatra, on 4 September 1953. His father is Rivai Said, and his mother is Saridahanum Syofyan. The Author obtained a Bachelor of Pharmacy from the Department of Pharmacy, Faculty of Mathematics and Natural Sciences, Padjajaran University, Bandung (1976), a Master of Science degree from the Bandung Institute of Technology (1984), and a Doctorate from the Department of Chemistry, Faculty of Mathematics and Natural Sciences, Andalas University, Padang (2011). Now the Author is a Professor and Researcher at the Faculty of Pharmacy, Andalas University, Padang. The Author also serves as Deputy Chair of Academic Affairs at the YPTIK Padang College of Pharmacy (STIFARM). The Author wrote the book "Principles of Chemical Examination" (Publisher UI-Press, 1995), translated the book "Pharmaceutical Statistics" (EGC Medical Book Publishers, 2010), and wrote "Chapter 4" in the book "Recent Research Advances in Biology Vol. 4" (International Book Publisher, India, and United Kingdom, 2020), and wrote the book "Chinese Petai (Leucaena leucocephala): Traditional Uses, Phytochemicals, and Pharmacological Activities" (Deepublish, Yogyakarta, 2021). The Author has also written articles in various international journals in various science fields, such as chemistry, biology, and pharmacy. 